Archaeological Journal

\title{
Notes on Durham, York and Manchester in Prehistoric Times
}

\author{
W. Boyd Dawkins Hon. M.A, D.Sc, F.R.S, F.S.A.
}

To cite this article: W. Boyd Dawkins Hon. M.A, D.Sc, F.R.S, F.S.A. (1909) Notes on Durham, York and Manchester in Prehistoric Times, Archaeological Journal, 66:1, 171-174, DOI: 10.1080/00665983.1909.10853114

To link to this article: http://dx.doi.org/10.1080/00665983.1909.10853114

册Published online: 17 Jul 2014.

Submit your article to this journal $\lceil\pi$

Џ Article views: 2

a

View related articles $₫$ 


\title{
NOTES ON DURHAM, YORK AND MANCHESTER IN PREHISTORIC TIMES. ${ }^{1}$
}

\author{
By W. BOYD DAWKINS, M.A, D.Sc, F.R.S, F.S.A, Hon. Professor in the University of \\ Manchester.

\section{Durham.}

The great mediaeval fortress (including the cathedral of Durham, crowning the heights and overlooking the river Wear and its marshes on three sides, and on the fourth the narrow neck separating it from the adjacent h11s occupies a site which could not fail to have been used by the prehistoric inhabitants of the district as a defence against their enemies. That it was so used is proved by its name, Dun Helme, the fort on the steep, island-like heights. The "Dun" points back to the remote time when the Goidels were the masters of the land, while " helm" marks the presence in historic times of the Scandinavian invaders of England. This evidence, fortunately, does not stand alone. A neighbouring height is occupied by an earthwork consisting of two fosses and ramparts cutting off the end of a promontory overlooking the river. It is known as Maiden Castle ("Magh," flat meadow, and "Dun," fort) the meadow-fort, a name given by the Goidels to their forts in other parts of Britain, as, for example, in Dorsetshire. We may therefore take it that both the above sites were occupied by the Goidels, and that there was a fortress at Durham on the lines of the present works as far back as the Bronze Age. It may further be noted that Durham is connected by a ridge-way passing from the neck to the north-east to join the system of prehistoric roads in the district. It is a remarkable fact that Durham was not linked up by the Roman engineers with their system of roads, and that no Roman remains have been discovered in its immediate neighbourhood. ${ }^{2}$

\footnotetext{
Igog.

1 Read before the Institute, May $5^{\text {th, }}$
}

${ }^{2}$ For this interesting fact I am indebted to Canon Greenwell. 
YORK.

I turn now from Durham to its greater sister York, the military centre of the Roman dominion in Britain. Eboracum has been so well described that it is unnecessary to touch upon Roman York. It is, however, clear, from the evidence ${ }^{1}$ of the prehistoric roads which point towards it on the wolds and moors of Yorkshire, that it was a centre of population before the Roman conquest, in the prehistoric Iron Age, and probably before. This conclusion is confirmed by the discovery of Neolithic and Bronze implements within its area. ${ }^{2}$

The site of prehistoric York was probably at the junction of the Fosse with the Ouse, where the slightly rising ground was defended by these rivers and their marshes. Unfortunately it cannot be fixed with accuracy because the ancient surface of the ground has been so covered by Roman and mediaeval ruins and so much modified by Norman and Angevin fortifications that no trace is left of fosse or ramp.

At York, as at Durham, the history of the name, as it appears to me, throws a flood of light on the antiquity of the site. Eboracum is the latinised form of some name such as Caer Ebrauc, and the "Ebor" in it can easily be explained by a river name such as Ebor, Ebro, or Eure. It would on this view be the city on the Eure. But it is clear that when the Romans conquered York it was not on the Eure, but on the Ouse, a name given to the river by the Goidels and used by their conquerors, the Brythons, long before the Roman conquest. In solving this difficulty a most interesting light is thrown on the prehistory of the district. The inhabitants in the Neolithic Age belonged to the Iberian race, and spoke a non-aryan tongue, which survives in the basque dialects of the Pyrenees. They gave the name Eure (Basque= water) to the great Yorkshire river, by which it is known for by far the greater part of its course. When the Goidels

1 Arcbaeological Fournal, lxi, 3०9-318.

2 Handbook of York (Brit. Assoc. 1 906). Prehistoric Archaeology, by G. A. Arden. 
occupied the lower portion of the river they called it the Ouse (water), while the older name still survived in the upper parts. If this view be accepted, when York was the city on the Eure it was during the Neolithic Age, when the Iberian tribes were in possession of the land. This view, based on the name, agrees with the evidence as to the antiquity of York based upon archaeological discovery. We may therefore view York as an inhabited site from the Neolithic Age down to to-day.

\section{Manchester.}

The Roman and prehistoric Manchester, embedded in the maze of streets of the modern city, have been described so well by Mr. Roeder (in the Journals of the Lancashire and Cheshire Antiquarian Society) that there is very little left for me to say. He has proved that, besides the Roman fort at the junction of the Medlock with the Irwell, there was an older stronghold on the rocky heights overlooking the junction of the Irk and the Irwell, and now occupied by Chetham's library, the grammar school and the cathedral. This was defended on the land side by a deep fosse, now known as a street (Hanging Ditch), passing from river to river. The two fortresses were linked together by a road and various buildings, during the Roman occupation. The name Mancunium or Mancocunium of the Antonine Itinerary is derived from Maen, the Brythonic for ' rock,' and applies more particularly to the red sandstone crag of the older fortress. It probably in Roman times included the newer four-square fortress. The other names Mamucium, (? Manutium) of the Itinerary, and Mameceaster (? Manigeceaster) of the Anglo-Saxon Chronicle A.D. 923, are probably variants of the same name and are based on Maen. It is therefore clear that the older stronghold belonged to the Brythons who gave their name to Britain in the prehistoric Iron Age. That Manchester was inhabited in the Bronze Age is proved by the discovery of implements belonging to that age within its limits. 
I74 PREHISTORIC DURHAM, YORK AND MANCHESTER.

We may therefore conclude that the three cities under consideration are of very different antiquity. York goes back to the Neolithic Age and was founded by people of Iberian race; Durham founded by the Goidels is of the Bronze Age; while Manchester in its name Brythonic carries us back to the prehistoric Iron Age. 